\title{
AN APPROACH FOR DESIGNING PASSIVE POWER FILTERS FOR INDUSTRIAL POWER SYSTEMS BY USING GRAVITATIONAL SEARCH ALGORITHM
}

\author{
Salih Tosun, Ali Oztürk, M. Mustafa Ertay, Mehmet Ali Yalçın, Ahmet Zengin
}

Original scientific paper

Harmonics are one of the important factors in determining the energy quality in power systems. Hence, eliminating or damping undesired harmonics is crucial in electrical power systems. Due to their low costs, Passive Power Filters (PPF) are widely used in industrial power systems to limit harmonics' undesired affects. In this study, a new approach to design a PPF for power systems using heuristic Gravitational Search Algorithms (GSA) is proposed. Traditional Try and Error (TAE) method is, first, utilized to eliminate harmonics in our model power system. Then, GSA is adopted to minimize the effective current value of Point of Common Coupling (PCC) in the same model system. Our results yield that our proposed method with GSA eliminates the harmonics effectively.

Keywords: GSA; Passive Power Filters; power systems harmonics

\section{Pristup projektiranju pasivnih energetskih filtara za industrijske energetske sustave primjenom algoritama za istraživanje gravitacije}

Izvorni znanstveni članak

Harmonike su jedan od najvažnijih čimbenika pri određivanju kvalitete energije u energetskim sustavima. Stoga je odstranjivanje ili prigušivanje nepoželjnih harmonika od bitne važnosti u elektroenergetskim sustavima. Zahvaljujući niskoj cijeni, pasivni energetski filtri - Passive Power Filters (PPF) uvelike se koriste $u$ industrijskim energetskim sustavima u svrhu ograničenja neželjenih učinaka harmonika. U ovom se radu predlaže novi pristup projektiranju PPF-a za energetske sustave koji primjenjuju heurističke algoritme za istraživanje gravitacije - Gravitational Search Algorithms (GSA). Najprije se, u svrhu eliminiranja harmonika u našem modelu energetskog sustava, primijenila tradicionalna metoda pokušaja i greške - Try and Error (TAE) method. Zatim su se primijenili GSA da bi se smanjila efektivna vrijednost struje u Point of Common Coupling (PCC) u sustavu istog modela. Rezultati pokazuju da naša predložena metoda s GSA učinkovito odstranjuje harmonike.

Ključne riječi: GSA; harmonike energetskog sustava; pasivni energetski filtri

\section{Introduction}

Today, power quality is important for consumers as well as electrical energy producers. Increasing use of nonlinear loads in electrical power systems has started to create serious harmonic problems in transmission and distribution system. This situation negatively affects the quality of the energy distributed to the customers. At the same time, the harmonic problems reduce the energy quality and affect the power systems in unwanted ways $[1,2]$. The harmonic currents produced by these loads create harmonic voltages in the system. The harmonic voltages in turn increase the harmonic currents over the linear and nonlinear loads $[1,2,3]$.

There are two solutions to limit the harmonic problems and improve power quality. The first method is the Load Analysis Method. The second is the line analysis method which utilizes active and passive power filters $[3,4,5]$. Due to their economical costs, PPFs are widely used in the industry as a solution to power quality problems $[6,7]$.

Heuristic methods are gaining momentum in filter design and harmonic elimination studies done in recent years. In filter design, by using Particle Swarm Optimization, minimization of harmonic currents and voltages has been achieved [8]. Similarly, Chou et al [9] have proposed an optimal design for various types of high-voltage, large harmonic power filters by using Simulated Annealing (SA) algorithms. In another study, by using knowledge-based chaotic evolutionary algorithms, a PPF was designed for a three-phase fullwave rectifier [10]. Berizzi et al have aimed to solve the dimension and placement problems of PPFs in power systems using genetic and micro genetic algorithms [11]. In a similar study, passive filters were designed based on genetic algorithms, and by using its source current rms value as the objective function, the minimization process was achieved [12]. Dehini et al. performed analyses on power quality and production cost of passive filters using Ant Colony algorithms [13]. Last but not least, researches have been conducted to regulate the power factor while eliminate harmonics [14].

In this study, by using MATLAB/Simulink, a PPF was designed and a harmonic analysis was performed for an industrial power system with GSA. First, harmonic values that disrupted the system were identified. Then, appropriate PPFs were designed for those harmonics using the proposed GSA method, and each one was applied to the system. The filter's effects on the harmonic disruptions were examined. Results show that our design conforms to the IEEE-519-1992 standard.

\section{Passive power filters}

PPFs are composed of R-L-C components. The underlying idea behind the PPFs is to determine the $\mathrm{L}$ and $\mathrm{C}$ values such that the filters reach their resonances at the level of frequency of the undesired harmonic components $[1,4]$. Fig. 1 shows the circuit configurations regarding the passive filters [16].

Single-tuned passive filters provide a low impedance path to suppress harmonic currents effectively $[6,7]$. Calculation of impedance of the filter is given in Eq. (1) [6]. 


$$
Z=R+j \cdot\left(w \cdot L-\frac{1}{w \cdot C}\right)
$$

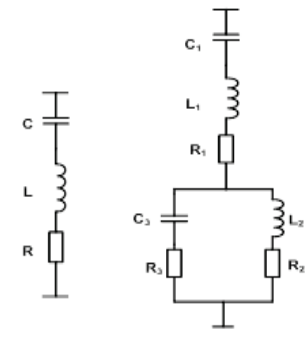

(a)

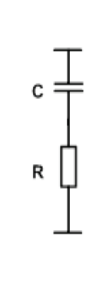

(c) (e)

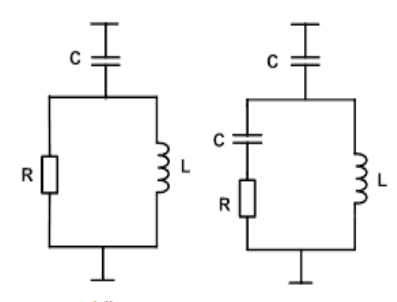

Figure 1 Passive tuned $(a, b)$ and passive high pass power filters $(c, d, e)$ [16]

$X_{\mathrm{L}}$ and $X_{\mathrm{C}}$ represent capacitor and inductor reactance at the main frequency respectively.The $Q_{\mathrm{f}}$ value is computed as given in Eq. (2) [4, 18, 19].

$Q_{\mathrm{f}}=\frac{V_{\mathrm{S}}^{2}}{X_{\mathrm{C}}-X_{\mathrm{L}}}$.

The filter's inductive and capacitive reactances for the $n$-th harmonic are calculated using Eq. (3) [4, 17, 18].

$$
X_{\mathrm{o}}=n \cdot X_{\mathrm{L}}=\frac{X_{\mathrm{C}}}{n}, X_{\mathrm{L}}=\frac{X_{\mathrm{C}}}{n^{2}}
$$

The filter size is obtained by Eq. (4) $[4,17,18]$

$$
Q_{\mathrm{f}}=\frac{V_{\mathrm{S}}^{2}}{X_{\mathrm{C}} \cdot\left(1-\frac{1}{n^{2}}\right)}
$$

$Q$ in Eq. (5) refers to the quality factor and determines the sharpness of the filter setting. In this respect, the filters may be low $Q$-type or high $Q$-type filter. Single-tuned filter quality factor is given by Eq. (5). Typical values of quality factor vary between 30 and 100 $[1,18,19]$.

$$
Q=\frac{X_{\mathrm{o}}}{R}
$$

\section{Gravitational search algorithm}

According to Newton's law of gravity, there is a force of gravity between every object pair in the universe. Objects attract each other by the gravity force. The principle says that two particles attract each other with forces directly proportional to the product of their masses divided by the square of the distance between them. This condition is represented by Eq. (6) where $F$ is the force in Newtons, $m_{1}$ and $m_{2}$ are the masses of the masses in kilograms, $\mathrm{G}$ is the gravitational constant, and $R$ is the distance between the masses in meters [20, 22, 23]. Newton's second law can be expressed as a mathematical formula for the amount of force needed to accelerate an object.The change in acceleration is directly proportional to the magnitude of the force applied to the object and inversely proportional to the mass of the object. This condition is represented by Eq. (7) where $a$ is acceleration $[20,22,23]$.

$F=G \cdot \frac{m_{1} \cdot m_{2}}{R^{2}}$,

$a=\frac{F}{m}$.

Gravitational Search Algorithm (GSA) is a new optimization algorithm. GSA works on the basis of Newton's law of gravity. GSA is proposed by Rashedi et al $[20 \div 24]$.

GSA can be considered as isolated masses system. This system fits Newton's laws of gravity and motion. In the Newton law of gravity, each mass attracts every other mass with a gravitational force that is defined by Eq. (6). Masses are defined to find the best solution in GSA. GSA simulates a set of masses that behave as point masses in an N-dimensional search space. According to this algorithm masses are defined as objects. Every object represents a solution of the problem. Heavy masses corresponding to the best solution, move more slowly than lighter ones $[20 \div 24]$.

In GSA, position of each mass in search space is a point in space and is taken in account as a solution to the problem. This position was given in Eq. (8). The masses initialize the positions of the $\mathrm{N}$ number of masses where $X_{i}^{d}$ represents the positions of the $i^{\text {th }}$ mass in the $d^{\text {th }}$ dimension and $N$ is the space dimension. $v_{i}^{d}$ also represents the velocity of each mass as given by Eq. (9) $[20 \div 24]$.

$X_{i}=x_{i}^{1}, x_{i}^{2}, \ldots \ldots, x_{i}^{d}, \ldots \ldots, x_{i}^{n} ; i=1,2,3, \ldots \ldots, N$
$V_{i}=v_{i}^{1}, v_{i}^{2}, \ldots \ldots, v_{i}^{d}, \ldots \ldots, v_{i}^{n} ; i=1,2,3, \ldots \ldots, N$

Taking into account other mass fitness values, each mass fitness value is calculated according to Eq. (10) and Eq. (11) where $M_{i}(t)$ represents the $i^{\text {th }}$ mass of $t$ time and $f_{i t}(t)$ is also fitness value of the $i^{\text {th }}$ mass, best $(t)$ and worst $(t)$ fitness of all masses. According to the type of optimization problem, these values change as minimum or maximum $[20 \div 24]$.

$$
\begin{aligned}
& m_{i}(t)=\frac{f i t_{i}(t)-\operatorname{worst}(t)}{\operatorname{best}(t)-\operatorname{worst}(t)}, \\
& M_{i}(t)=\frac{m_{i}(t)}{\sum_{j=1}^{N} m_{j}(t)}, \\
& G(t)=G\left(t_{0}\right) \cdot \mathrm{e}^{-k \cdot \frac{t}{T}} .
\end{aligned}
$$

Eq. (12) calculates gravitational constant $G(t)$ in time t. $T$ is number of iterations, $G\left(t_{0}\right)$ initial value of gravitational constant, $t$ also refers to the moment of iteration [20-24].

$F_{i j}^{d}$ is a force acting on mass $i$ from mass $j$ at $d^{\text {th }}$ dimension and $t^{\text {th }}$ iteration is computed as Eq. (13) 
where, $m_{p i}(t), m_{a j}(t)$ active and passive masses respectively, at iteration $t R_{i j}(t)$ is the Euclidian distance between two masses $i^{\text {th }}$ and $j^{\text {th }}$ at iteration $t . \varepsilon$ is a small constant $[20 \div 24]$.

$$
F_{i j}^{d}=G(t) \cdot \frac{m_{p i}(t) \cdot m_{a j}(t)}{R_{i j}(t)+s} \cdot\left(x_{j}^{d}(t)-x_{j}^{d}(t)\right) .
$$

The total force acting on mass $i$ in the dimension $d$ is calculated by Eq. (14) where rand $_{j}$ is a random number in the interval $[0,1]$ Eq. (15). Find the acceleration of mass $i$ in the $d$-th dimension [20 $\div 24]$.

$$
\begin{aligned}
& F_{i}^{d}=\Sigma_{J \in N, j \neq i}^{N} \text { rand }_{j} \cdot F_{i i}^{d}(t), \\
& a_{i}^{d}(t)=\frac{F_{i}^{d}}{M_{i}(t)} .
\end{aligned}
$$

Velocity and position vectors for each mass $i$ are recalculated for the new iteration according to Eq. (16) and Eq. (17). [20 $\div 24,26]$.

$$
\begin{aligned}
& v_{i}^{d}(t+1)=\operatorname{rand}_{i} \cdot v_{i}^{d}(t)+a_{i}^{d}(t), \\
& x_{i}^{d}(t+1)=\operatorname{rand}_{i} \cdot x(t)+v_{i}^{d}(t+1) .
\end{aligned}
$$

By using Eqs. (10) to (17), position and velocity values for each mass are calculated repeatedly until it reaches the number of iteration [26]. GSA flowchart is given in Fig. 2 [24, 25].

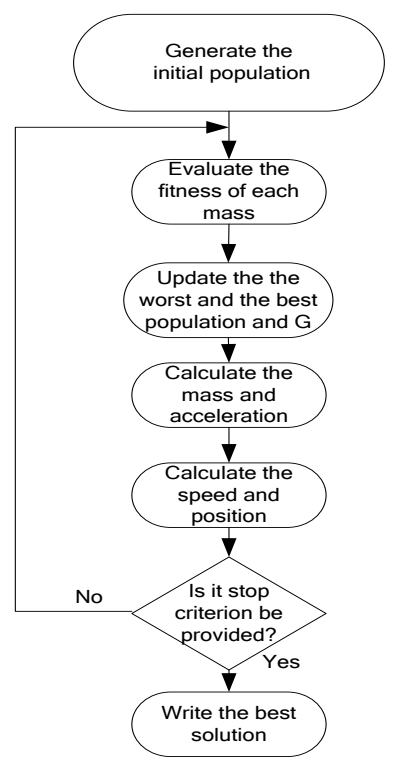

Figure 2 Flowchart of GSA

\section{Problem definition}

In this study, we used MATLAB/Simulink to model our system given in Fig. 3 [3]. The initial power factor prior to the PPF adopted is 0,82 [3]. Tab. 1 lists the harmonic values before the PPF application [3]. As seen in Tab.1, the disturbance rates in the harmonic currents are 13,2 \% . Fig. 4 illustrates the harmonic currents as a bar graph. Measurement point is PCC bus which is demonstrated in Fig. 3. The current values are total current values which are obtained from PCC bus. All the harmonic values are RMS values which are obtained from power gui in MATLAB simulink. Additionally, Fig. 5 shows the current and voltage wave shapes of the system.
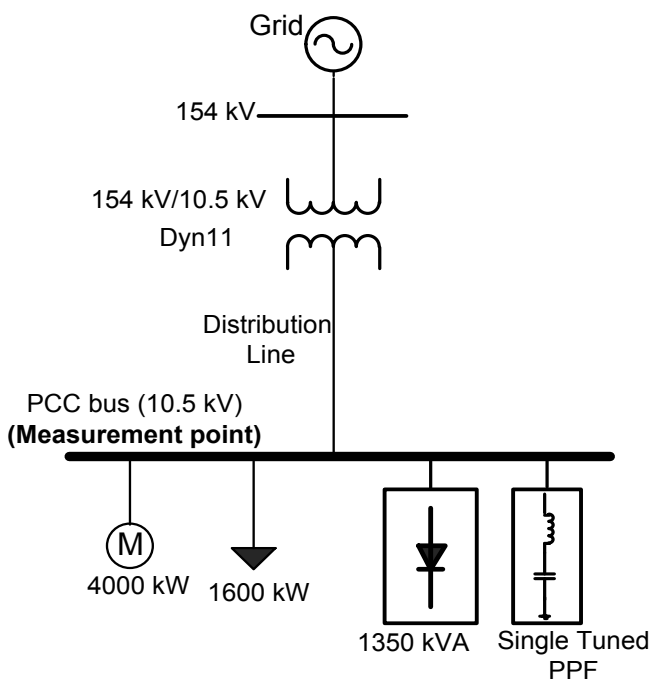

Figure 3 Power System where PPF is to be adopted

Table 1Harmonic value prior to PPF

\begin{tabular}{|c|c|c|c|c|c|c|c|c|}
\hline Harmonics & 1 & 5 & 7 & 11 & 13 & 17 & 19 & TDD (\%) \\
\hline Currents & 363,9 & 34,0 & 24,16 & 14,99 & 13,03 & 9,77 & 8,49 & 13,2 \\
\hline
\end{tabular}

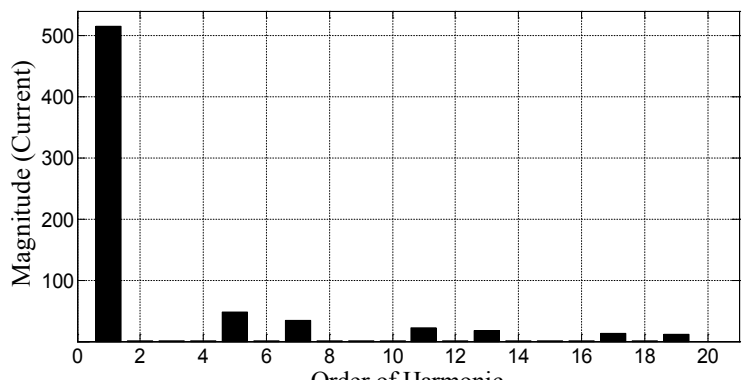

Figure 4 Harmonic current magnitudes prior to PPF

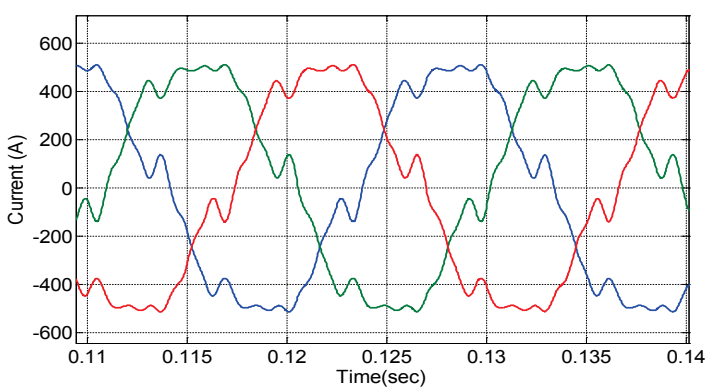

(a)

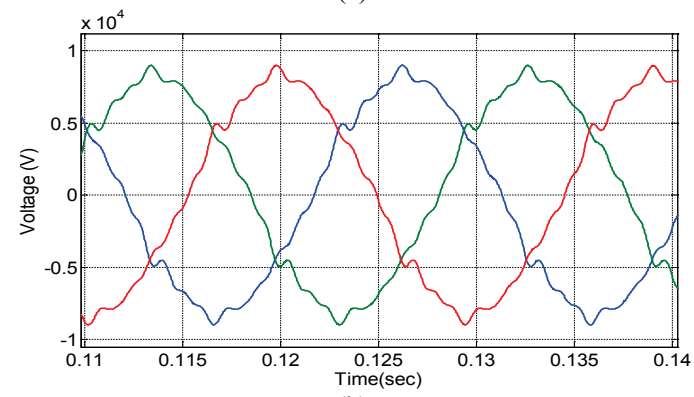

(b)

Figure 5(a) Current and (b) Voltage waves shapes prior to PPF 
The Simulink model is shown in Fig. 6. Nonlinear loads were modelled by current sources. Motor loads were modelled as impedance loads $[3,4,6]$.

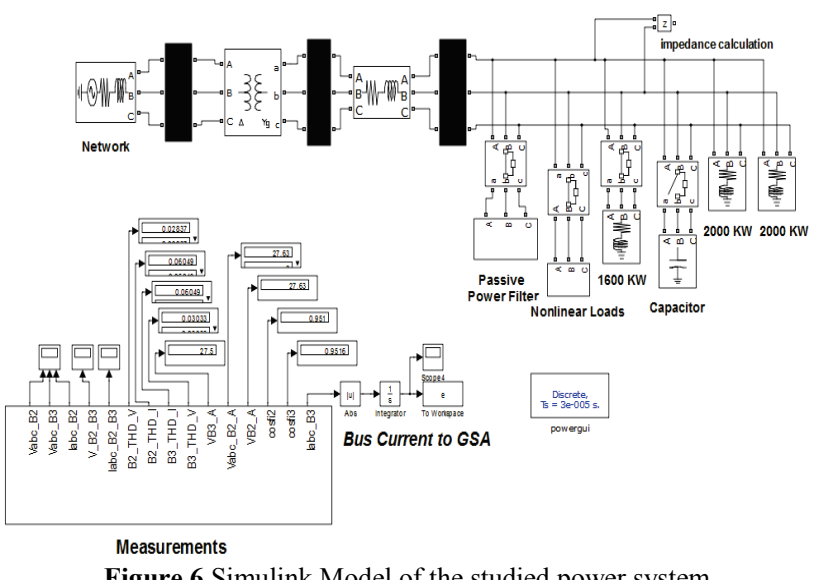

Figure 6 Simulink Model of the studied power system

\section{Solution}

Because the passive filters use reactive power compensation at the base frequency, the system's reactive power needs must first be identified [1, 6, 7]. Eq. (14) computes the reactive power needs where $Q_{\mathrm{c}}$ is 2100 kVAr [6].

$Q_{\mathrm{c}}=P \cdot\left(\tan \theta_{1}-\tan \theta_{2}\right)$

Power factor value will be increased from 0,82 to 0,95 and the required capacitor's reactance value is computed by Eq. (15) $[6,17,18]$.

$X_{\mathrm{c}}=\frac{V \mathrm{~s}^{2}}{Q_{\mathrm{c}}}$

The filter's reactance at its resonance level is computed using Eq. (15). According to industrial power systems' short circuit/Load current ratio the IEEE 5191992 standard requires the harmonic current threshold to be $5 \%[3,15]$. Nevertheless, total harmonic current value is observed to be $13,2 \%$ and is given in Tab. 1 . It is assumed that the industrial power system runs under full load. The Simulink model in Fig. 6 was used, and the filters were determined based on the obtained harmonic current values. First, analyses with various power factors were conducted for the $5^{\text {th }}$ and $7^{\text {th }}$ harmonic amplitudes. Then, the same analysis was repeated for the $5^{\text {th }}, 7^{\text {th }}$, and $11^{\text {th }}$ harmonics. In the first stage of the study, the filters were designed by TAE so as to draw the least amount of current. The design was repeated using GSA. For the risk of harmonic problems with power system harmonic values are taken lower than the harmonic order such as $5^{\text {th }}$ $=4,8^{\text {th }}$, it corresponds to $4 \%$ of harmonic. The reactive power values are obtained according to this resonance setting. The results are given in Tabs. 2, 3 and 4. The aim is to minimize the Point of Common Coupling (PCC) current's effective value, as expressed by the objective function in Eq. (16), when running GSA. This is the linecurrent value least affected by harmonics. While the algorithms are running, the filters' reactive power values are taken with variable constraints such as given by Eq. (17). In addition, the system's power factor is added to the algorithm with the constraint given by Eq. (18).

$$
\begin{aligned}
& F F=\min \left(\Sigma I_{\mathrm{PCC}}\right), \\
& Q_{\mathrm{cmin}} \leq Q_{5^{\mathrm{th}}} \leq Q_{\mathrm{cmax}}, \\
& Q_{\mathrm{cmin}} \leq Q_{7^{\mathrm{th}}} \leq Q_{\mathrm{cmax}}, \\
& Q_{\mathrm{cmin}} \leq Q_{11^{\mathrm{th}}} \leq Q_{\mathrm{cmax}}, \\
& \cos \varphi_{\min } \leq \cos \varphi \leq \cos \varphi_{\max } .
\end{aligned}
$$

We observed that $5^{\text {th }}$ and $7^{\text {th }}$ harmonics have the highest currents. So, we used them as the base to design the filters. In similar studies utilizing GSA, first case, it was determined that the $5^{\text {th }}$ and $7^{\text {th }}$ harmonics have the highest currents, and then filters were applied to these harmonics. After the filters were applied to the system, the resulting harmonic amplitudes, harmonic current and harmonic voltage values, and power factor values are displayed in Tab. 2. As seen in Tab. 2, the PCC current value drops in a filter less system from 363,9 A to 318,5 A When we had a system with the power factor of 0,952 and

\begin{tabular}{|c|c|c|c|c|c|c|c|c|c|c|c|c|}
\hline Method & $H$ & $O_{c}(\mathrm{kVAr})$ & 1 & 5 & 7 & 11 & 13 & 17 & 19 & $T H D$ & (T) & $P E$ \\
\hline Without filter & - & - & 363,9 & 34,00 & 24,16 & 14,99 & 13,03 & 9,77 & 8,49 & 5,49 & 13,2 & 0,82 \\
\hline TAE & $\begin{array}{l}5^{\text {th }} \\
7^{\text {th }}\end{array}$ & $\begin{array}{c}1410 \\
690\end{array}$ & 318,5 & 10,23 & 4,84 & 9,43 & 8,56 & 6,65 & 5,82 & 3,01 & 6,03 & 0,952 \\
\hline GSA & $\begin{array}{l}5^{\text {th }} \\
7^{\text {th }}\end{array}$ & $\begin{array}{c}1448,3 \\
630,1\end{array}$ & 318,8 & 9,89 & 5,20 & 9,59 & 8,68 & 6,73 & 5,89 & 3,05 & 6,05 & 0,951 \\
\hline
\end{tabular}
the reactive power of $2100 \mathrm{kVAr}$. Current and voltage harmonics values without a filter are measured as 13,2\%

\begin{tabular}{|c|c|c|c|c|c|c|c|c|c|c|c|c|}
\hline Method & $H$ & $Q_{\mathrm{f}}(\mathrm{kVAr})$ & 1 & 5 & 7 & 11 & 13 & 17 & 19 & $T H D_{\mathrm{v}}(\%)$ & $T D D(\%)$ & $P F$ \\
\hline Without filter & - & - & 363,9 & 34,00 & 24,16 & 14,99 & 13,03 & 9,77 & 8,49 & 5,49 & 13,2 & 0,82 \\
\hline TAE & $\begin{array}{l}5^{\text {th }} \\
7^{\text {th }} \\
11^{\text {th }}\end{array}$ & $\begin{array}{c}1510 \\
710 \\
380\end{array}$ & 312,4 & 9,92 & 5,03 & 1,59 & 5,17 & 4,9 & 4,41 & 1,98 & 4,49 & 0,974 \\
\hline GSA & $\begin{array}{c}5^{\text {th }} \\
7^{\text {th }} \\
11^{\text {th }}\end{array}$ & $\begin{array}{c}1652,8 \\
508,3 \\
402,2\end{array}$ & 312,8 & 9,01 & 6,27 & 1,59 & 5,28 & 5,0 & 4,5 & 2,02 & 4,48 & 0,972 \\
\hline
\end{tabular}
and $5,49 \%$ respectively.

Table 2 Harmonic analysis with filter in first case

Table 3 Harmonic analysis with filter in second case 
With a filter using GSA, we measured lower values as $6,05 \%$ and $3,05 \%$. We measured these values where the power factor was 0,951 and the reactive power was 2078 kVAr. Nevertheless, these reduced values are above the IEEE standard values. Because of the constraints, According to the IEEE 519-1992 standards, harmonic currents must be $5 \%$ or less. We repeated the process by increasing the reactive power value to $2600 \mathrm{kVAr}$ and redesigned filters for $5^{\text {th }}, 7^{\text {th }}$, and $11^{\text {th }}$ harmonics. Because appropriate values were not obtained in the filter study with the $5^{\text {th }}$ and $7^{\text {th }}$ harmonics, the process was repeated. In this second case simulation, the filters were distributed as seen in Tab. 3 1510, 710 and $380 \mathrm{kVAr}$ for TAE and redesigned filters for $5^{\text {th }}, 7^{\text {th }}$, and $11^{\text {th }}$ harmonics. Then, we provided the results obtained by both traditional and GSA methods in Tab. 3 and showed the changes in the objective function with each iteration in Fig. 7.

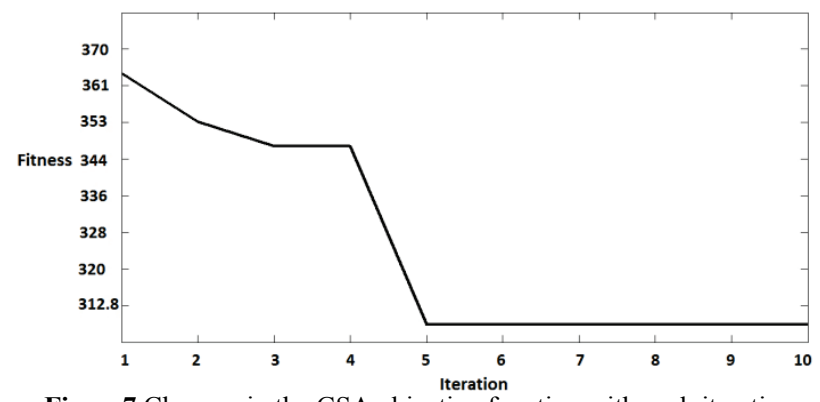

Figure7 Changes in the GSA objective function with each iteration (for $2600 \mathrm{kVAr} 5^{\text {th }}, 7^{\text {th }}$ and $11^{\text {th }}$ harmonics)

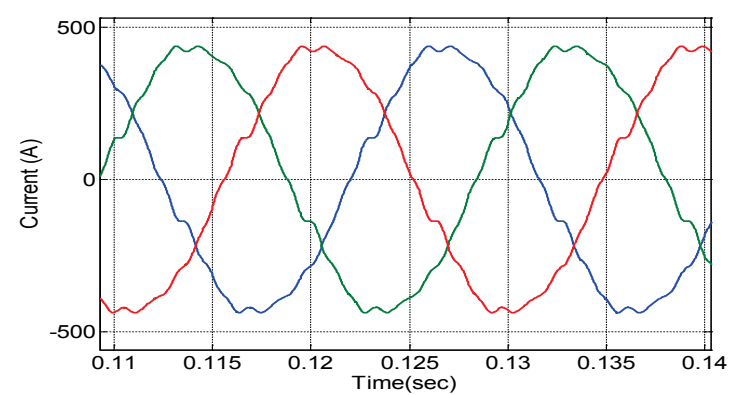

(a)

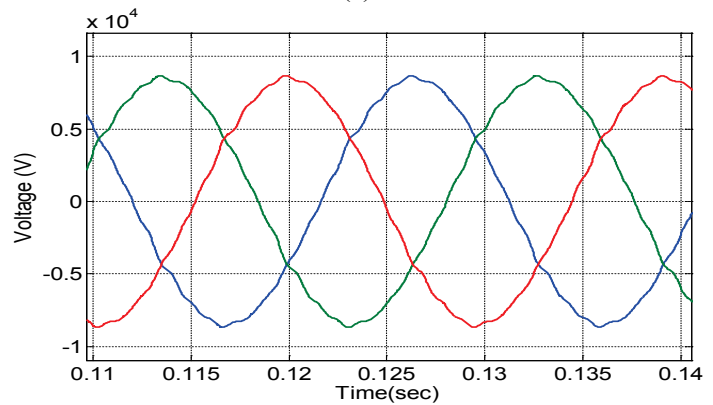

(b)

Figure 8 Current wave (a) and (b) voltage wave shapes after PPF with GSA

When we wanted to destroy the $5^{\text {th }}, 7^{\text {th }}$, and $11^{\text {th }}$, harmonics, current and voltage harmonics values without a filter were measured as $13,2 \%$ and 5,49\% respectively. With a filter using GSA, we measured lower values as $4,48 \%$ and $2,02 \%$. We measured these values where the power factor was 0,972 . Those reduced values are in compliance with the IEEE standards. In this case, with the proposed GSA the results of current and voltage wave shapes are shown in Fig. 8. The process was repeated by increasing the reactive power value to $3100 \mathrm{kVAr}$ and redesigning filters for the $5^{\text {th }}, 7^{\text {th }}$, and $11^{\text {th }}$ harmonics. Because individual harmonic value of the $17^{\text {th }}$ harmonic does not comply with IEEE standard. The changes in the objective function with each iteration when the GSA was run are shown in Fig. 9. According to Tab. 5, the PCC current value dropped from 363,9 A to 308,8 A against filterless system with GSA. The power factor was 0,9889 . Harmonic current and voltage values without a filter were $13,2 \%$ and $5,49 \%$ respectively. With a filter using GSA, the measured, lower values were $4,06 \%$ and $1,84 \%$. These reduced values are in compliance with the IEEE standards [15].

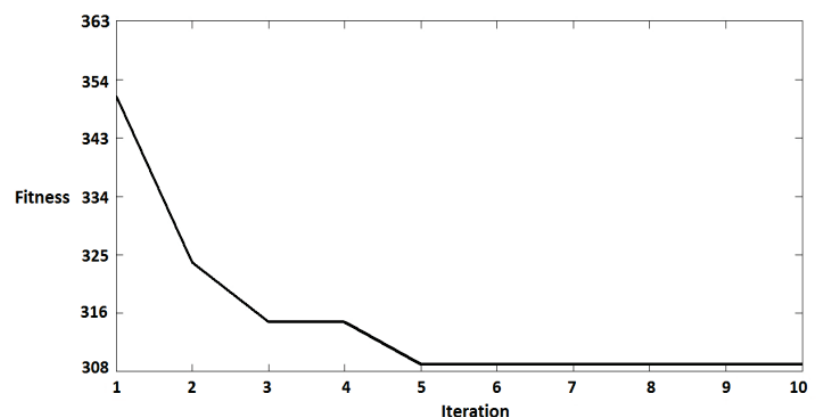

Figure 9 Changes in the GSA objective function with each iteration (for $3100 \mathrm{kVAr}$ and $5^{\text {th }}, 7^{\text {th }}$ and $11^{\text {th }}$ harmonics)

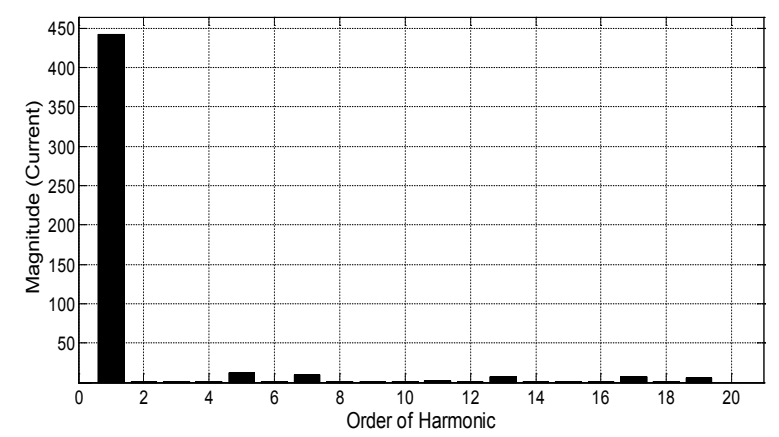

Figure 10 Bar graphic of current after the last designed PPF with GSA

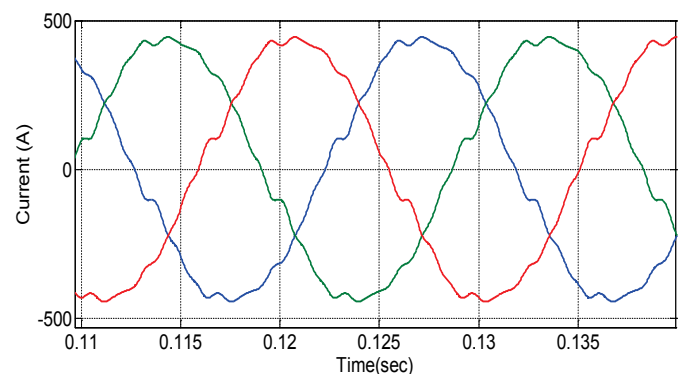

(a)

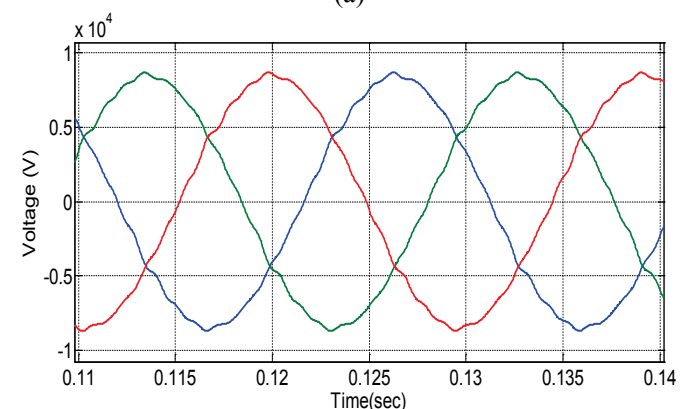

(b)

Figure 11(a) Current wave and (b) Voltage wave shapes after the PPF with GSA (With last filter values) 
Current and voltage wave shapes with GSA filters are displayed in Fig. 11. Current and voltage wave shapes are seen to be better, after the filters were applied to the $5^{\text {th }}$, $7^{\text {th }}$ and $11^{\text {th }}$ harmonics, than with a filterless system. Tab. 4 gives the filter parameters obtained as a result of last GSA filter design study. Fig. 10 shows the bar graphic of harmonic current magnitudes after the last GSA based filter was applied. Also the individual current magnitudes of system with the last designed PPF based on GSA are in compliance with IEEE 1519-1992 standard. When reactive power constraints were given properly the IEEE standards for both general and individual harmonic values are obtained in proposed GSA optimization.

Table 4 Thefilter parameters obtained as a result of GSA

\begin{tabular}{|c|c|c|c|c|}
\hline Methods & Filter Parameters & $R / \Omega$ & $L / H$ & $C / F$ \\
\hline \multirow{3}{*}{ TAE } & $5^{\text {th }}$ & 0,1334 & 0,0088 & $4,9717 \mathrm{e}-005$ \\
& $7^{\text {th }}$ & 0,1840 & 0,0086 & $2,5436 \mathrm{e}-005$ \\
& $11^{\text {th }}$ & 0,2571 & 0,0076 & $1,1462 \mathrm{e}-005$ \\
\hline \multirow{3}{*}{ GSA } & $5^{\text {th }}$ & 0,1308 & 0,0087 & $5,0682 \mathrm{e}-005$ \\
& $7^{\text {th }}$ & 0,2070 & 0,0097 & $2,2609 \mathrm{e}-005$ \\
& $11^{\text {th }}$ & 0,2452 & 0,0072 & $1,2019 \mathrm{e}-005$ \\
\hline
\end{tabular}

Table 5 Harmonic analysis with filter in third case

\begin{tabular}{|c|c|c|c|c|c|c|c|c|c|c|c|c|}
\hline Method & $H$ & $Q_{\mathrm{f}}(\mathrm{kVAr})$ & 1 & 5 & 7 & 11 & 13 & 17 & 19 & $T H D v(\%)$ & $T D D(\%)$ & $P F$ \\
\hline Without filter & - & - & 363,9 & 34,00 & 24,16 & 14,99 & 13,03 & 9,77 & 8,49 & 5,49 & 13,2 & 0,82 \\
\hline TAE & $\begin{array}{c}5^{\text {th }} \\
7^{\text {th }} \\
11^{\text {th }}\end{array}$ & $\begin{array}{c}1800 \\
900 \\
400\end{array}$ & 308,6 & 8,70 & 4,08 & 1,56 & 4,92 & 4,62 & 4,16 & 1,84 & 4,07 & 0,99 \\
\hline GSA & $\begin{array}{c}5^{\text {th }} \\
7^{\text {th }} \\
11^{\text {th }}\end{array}$ & $\begin{array}{c}1835,3 \\
800,4 \\
419,9\end{array}$ & 308,8 & 8,49 & 4,47 & 1,51 & 4,89 & 4,63 & 4,17 & 1,84 & 4,06 & 0,9889 \\
\hline
\end{tabular}

\section{Conclusion}

Harmonics are considered to be a factor that decreases energy quality. They also affect other recipients fed by the same busbar. Moreover, additional losses in the system are caused by undesired faults in the devices. The results of the GSA based filter designs made to resolve these harmonic problems in the system were discussed in this paper. In this study, GSA based single-tuned passive power filter designs and harmonic analysis was performed on an industrial power system. The design study was conducted with various power factors and by applying filters to various harmonics. The design study was conducted with various power factors and by applying filters to various harmonics. MATLAB/Simulink was used in this study. Appropriate filter values were established with the proposed GSA technique and applied to an example power system. With these filters, the current and voltage values came to a level acceptable by the IEEE 519-1992 standards. As a result, harmonic voltage and current values obtained from the application of an example power system with GSA are very close to classical method harmonic values. However, the GSA method obtained results more quickly and effectively/efficiently, without the need for trials. In conclusion, the results show that GSA is an effective solution in the design of passive power filters.

\section{Acknowledgements}

This work has been presented at the $2^{\text {nd }}$ National Anatolia Energy Symposium (AES) 2-4 May 2013, Diyarbakir, TURKEY.

\section{References}

[1] Kocatepe, C.; Uzunoğlu, M.; Yumurtacı, R.; Karakaş, A.; Arıkan, O. Elektrik Tesislerinde Harmonikler. // BirsenYayınevi, İstanbul, Turkey, 2003.

[2] Bhonsle, D. C.; Kelkar, R. B. Harmonic Pollution Survey and Simulation of PassiveFilter using MATLAB // In: International Conference on Recent Advancements in
Electrical, Electronics and Control Engineering; 15-17 December 2011; Surat, India: IEEE pp. 230-236. DOI: 10.1109/ICONRAEeCE.2011.6129785

[3] Ertay, M. M.; Duru, H. T. Harmonic analysis and passive power filter design for a medium voltage power system according to IEEE standards. // Energy Education Science and Technology Part A: Energy Science and Research. 29, (2012), pp. 1253-1262.

[4] Ertay, M. M.; Alboyacı, B.; Duru, H. T.; Yeğin, E. M. Endüstriyel Güç Sistemlerinde Oluşan Harmoniklerin Pasif Filtrelerle yok edilmesi. // In: IV. Enerji Verimliliği ve Kalitesi Sempozyumu; Kocaeli, Türkiye, Mayıs 2011, pp. 58-63.

[5] Izhar, M.; Hadzer, C. M.; Syafrudin, M.; Taib, S.; Idris, S. Performance for Passive and Active Power Filter in Reducing Harmonics in the Distribution System. // In: National Power \& Energy ConferenceMalaysia, 2004; pp. 104-108.

[6] De La Rosa, F. C. Harmonics and Power Systems. Missouri, U.S.A.: Taylor \& Francis Group, LLC, 2006. DOI: $10.1201 / 9781420004519$

[7] Dugan, R. C.; McGranaghan, M. F.; Santoso, S.; Beaty, H. W. Electrical Power Systems Quality. Second Edition: McGraw-Hill, 2004.

[8] Sharaf, A. M.; Adel, A.; El-Gammal, A. A Particle Swarm Optimization Technique (PSO) for Power Filter Design. // In: 2009 Third UKSim European Symposium on Computer Modeling and Simulation, 25-27 Nov. 2009: pp. 395-399. DOI: 10.1109/EMS.2009.15

[9] Chou, C.; Lio, C.; Lee, J.; Lee, K. Optimal Planning Of Large Passive-Harmonic-Filters Set At High Voltage Level. // IEEE Transactions on Power Systems. 15, 1(2000), pp. 433-441. DOI: $10.1109 / 59.852156$

[10] Guo, Y.; Zhou, J.; Cheng, J.; Jiang, X. Optimal Design of Passive Power Filters Based on Knowledge-based Chaotic Evolutionary Algorithm. // In: Fourth International Conference on Natural Computation; 18-20 Oct. 2008: pp. 535-539. DOI: 10.1109/ICNC.2008.899

[11] Berizzi, A.; Bovo, C. The Use of Genetic Algorithms for the Localization and the Sizing of Passive Filters. // In: $9^{\text {th }}$ International Conf. on Harmonics and Quality of Power; 2000-1: pp. 19-25. DOI: 10.1109/ICHQP.2000.896992

[12] Verma, V.; Singh, B. Genetic Algorithm-Based Design of Passive Filters for Offshore Applications. // IEEE Transactions on Industry Applications. 46, 4(2010), pp. 1295-1303. DOI: 10.1109/TIA.2010.2049629 
[13] Dehini, R.; Sefiane, S. Power Quality and Cost Improvement by Passive Power Filters Synthesis Using Ant Colony Algorithm. // Journal of Theoretical and Applied Information Technology. 23, 2(2011), pp. 70-79.

[14] Hsiao, Y. T. Design of Filters for Reducing Harmonic Distortion and Correcting Power Factor in Industrial Distribution Systems. // Tamkang Journal of Science and Engineering. 4, 3(2001), pp. 193-199.

[15] IEEE standart, IEEE SM 519-1992, Recommended Practice and Requirements for Harmonic Control in Electrical Systems. 2 (Revision of IEEE Std 519-1981) 1992.

[16] Akagi, H. Modern active filters and traditional passive filters. // Bulletin of the Polish Academy of Sciences Technical Sciences. 54, 3(2006), pp. 255-269.

[17] Das, J. C. Passive Filters Potentialities and Limitations. // IEEE Transactions on Industry Applications. 40, 1(2004), pp. 232-241. DOI: 10.1109/TIA.2003.821666

[18] Arrillaga, J.; Watson, N. R. Power System Harmonics. Second Edition, USA: John Wiley, 2003. DOI: 10.1002/0470871229

[19] Wakileh, G. J. Power Systems Harmonics. Fundemantal Analysis and Filter Design: Springer, 2001. DOl: 10.1007/978-3-662-04343-1

[20] Rashedi, E.; Nezamabadi, H.; Saryazdi, S. GSA: A Gravitational Search Algorithm. // Information Sciences. 179, 13(2009), pp. 2232-2248. DOI: 10.1016/j.ins.2009.03.004

[21] Rashedi, E.; Nezamabadi, H.; Saryazdi, S. BGSA: Binary gravitational search algorithm. // Computer Science. 9, 3(2010), pp. 727-745. DOI: 10.1007/s11047-009-9175-3

[22] Holliday, D.; Resnick, R.; Walker, J. Fundamentals of physics 4th edition; John Wiley and Sons, 196-197, 1993.

[23] Mansuri, R.; Nasseri, F.; Khorrami, M. Effective time variation of $\mathrm{G}$ in a model universe with variable space dimension. // Physics Letters. 1999, pp. 194-200. DOl: 10.1016/S0375-9601(99)00449-1

[24] Rashedi, E. Gravitational Search Algorithm. M.Sc. Thesis, Shahid Bahonar University of Kerman, Kerman, Iran, 2007.

[25] Rostami, A. S.; Bernety, H. M.; Hosseinabadi, A. R. A Novel and Optimized Algorithm to Select Monitoring Sensors by GSA. // In: $2^{\text {nd }}$ International Conference on Control, Instrumentation and Automation (ICCIA); 27-29 Decembert, 2011, pp. 829-834. DOI: 10.1109/ICCIAutom.2011.6356769

[26] Singh, J. D. Economic Load Dispatch Problem with Valve Point Effect through Gravitational Search Algorithm. // In: International Conf. on Computing and Control Engineering (ICCCE 2012); 12-13 April, 2012.

\section{Authors' addresses}

Salih Tosun, Assist. Prof. Dr.

Department of Electrical \& Electronics Engineering, Duzce University, Technology Faculty, 81620 Duzce, Turkey

E-mail: salihtosun@duzce.edu.tr

\section{Ali Oztürk, Assoc. Prof. Dr.}

Department of Electrical \& Electronics Engineering, Duzce University, Engineering Faculty,

81620 Duzce, Turkey

E-mail: aliozturk@duzce.edu.tr

\section{Mustafa Ertay, Assist. Prof. Dr.}

Department of Electrical \& Electronics Engineering, Duzce University, Technology Faculty,

81620 Duzce, Turkey

E-mail: mustafaertay@duzce.edu.tr

\section{Ali Yalçın, Prof. Dr.}

Department of Electrical \& Electronics Engineering, Sakarya University, Engineering Faculty, Sakarya, Turkey
E-mail: myalcin@sakarya.edu.tr

\section{Ahmet Zengin Assoc. Prof. Dr.}

Department of Computer Engineering, Sakarya University Technology Faculty, Sakarya, Turkey

E-mail: azengin@sakarya.edu.tr 